\title{
A missional perspective on funerals and bereavement counselling
}

\begin{tabular}{|c|c|}
\hline \multicolumn{2}{|l|}{$\begin{array}{l}\text { Authors: } \\
\text { Peter Kotze }{ }^{1} \\
\text { C.J.P. (Nelus) Ni }\end{array}$} \\
\hline \multicolumn{2}{|c|}{$\begin{array}{l}\text { Affiliations: } \\
{ }^{1} \text { Department of Science } \\
\text { Religion and Missiology, } \\
\text { Faculty of Theology, } \\
\text { University of Pretoria, } \\
\text { South Africa }\end{array}$} \\
\hline \multicolumn{2}{|c|}{$\begin{array}{l}\text { Note: } \\
\text { This article is based on } \\
\text { research done for an MTh } \\
\text { degree by Peter Kotze "n } \\
\text { Missionale perspektief } \\
\text { op begrafnisse en } \\
\text { sterwensbegeleiding in } \\
\text { 'n sekulêre samelewing', } \\
\text { Department of Science of } \\
\text { Religion and Missiology, } \\
\text { Faculty of Theology, } \\
\text { University of Pretoria (2014). }\end{array}$} \\
\hline \multicolumn{2}{|c|}{$\begin{array}{l}\text { Correspondence to: } \\
\text { Nelus Niemandt }\end{array}$} \\
\hline \multicolumn{2}{|c|}{$\begin{array}{l}\text { Email: } \\
\text { nelus@pixie.co.za }\end{array}$} \\
\hline \multicolumn{2}{|c|}{$\begin{array}{l}\text { Postal address: } \\
\text { Private Bag X20, Hatfield } \\
0028 \text {, South Africa }\end{array}$} \\
\hline \multicolumn{2}{|c|}{$\begin{array}{l}\text { Dates: } \\
\text { Received: } 12 \text { Feb. } 2015 \\
\text { Accepted: } 26 \text { May } 2015 \\
\text { Published: } 25 \text { Aug. } 2015\end{array}$} \\
\hline \multicolumn{2}{|c|}{$\begin{array}{l}\text { How to cite this article: } \\
\text { Kotze, P. \& Niemandt, } \\
\text { C.J.P., 2015, 'A missional } \\
\text { perspective on funerals and } \\
\text { bereavement counselling', } \\
\text { HTS Teologiese Studies/ } \\
\text { Theological Studies 71(3), } \\
\text { Art. \#2912, 9 pages. http:// } \\
\text { dx.doi.org/10.4102/hts. } \\
\text { v71i3.2912 }\end{array}$} \\
\hline \multicolumn{2}{|c|}{$\begin{array}{l}\text { Copyright: } \\
\text { (C) 2015. The Authors. } \\
\text { Licensee: AOSIS } \\
\text { OpenJournals. This work is } \\
\text { licensed under the Creative } \\
\text { Commons Attribution } \\
\text { License. }\end{array}$} \\
\hline \multicolumn{2}{|l|}{ Read online: } \\
\hline 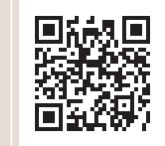 & $\begin{array}{l}\text { Scan this QR } \\
\text { code with your } \\
\text { smart phone or } \\
\text { mobile device } \\
\text { to read online. }\end{array}$ \\
\hline
\end{tabular}

This article deals with the importance of a missional approach to the funeral and bereavement counselling process in congregational praxis in the midst of a context of secularisation. The creation of a missional perspective on the funeral and bereavement counselling could support the nature and praxis of a congregation in a secular society, especially if the congregation finds its relevance in the expression of the missio Dei. The basic theoretical research for missional ecclesiology, which is the systematic study directed toward greater knowledge of the fundamental aspects of missional ecclesiology (National Science Foundation 1953:38), is based on the premise that God is the source of all missions. The expression missio Dei means to join God in the mission he is already busy with in the world. As the one who sends, God the Father sends the Son, the Son sends the Holy Spirit, and the Holy Spirit sends the church. The church only participates in the mission God is already busy with. It is a mission that uses both words and deeds and brings hope in the midst of tragedy. It is the hope of the kingdom of God and the incarnation of Christ that can already be experienced and expressed in the present. It is also the hope of the transformation of everything to form a new heaven and earth. Hope and mission can therefore not be separated. The concretisation of the expression of the kingdom of Christ in the world is hope, and a strong emphasis is therefore placed on mission as action in hope. Hope must be present where tragedy reigns, and the funeral and bereavement counselling can be used as a vehicle for this hope. Hope can then become an instrument of healing. The church can thus participate in God's mission in the midst of tragedy and make an impact on society by taking on a missional character of hope.

\section{Introduction}

The western church currently finds itself in the midst of a changing context and needs to adapt to its surroundings in order to avoid deterioration (Frost \& Hirsch 2011:21). This context is defined by the rise of secularism. Van der Ven (1993:137) describes secularism as the separation of the state from religion, or the diversification and subsequent equality of all religions. Greene and Robinson (2008:74) add to this by stating that secularism has the exclusion of religion from society as its goal.

According to the U.S. Census Bureau, the current global population is around 7.02 billion people (2013). Of these, only $32.8 \%$ are Christians, whilst $22.8 \%$ are Muslims, $13.3 \%$ Hindus, $6.5 \%$ Chinese folk religions, $6.4 \%$ Buddhists, $0.3 \%$ Sikhs, and $0.2 \%$ are Jews. Thus, according to these percentages more than $82 \%$ of the global population practises at least some form of religion. It also shows that there is a large diversity in terms of religion. These percentages also agree with the findings of Ross (2013) and the Global Atlas of Christianity, henceforth GAC (Johnson \& Ross 2010:36), who state that $82 \%-83 \%$ of the world population adheres to at least some form of religion, and that religious diversity has greatly increased (Johnson \& Ross 2010:32).

A Win Gallop International poll, henceforth WGI (2012:2), showed around 23\% of the global population as non-religious. Win Gallop International is a market research and polling association, doing multi-country surveys, and is made up of 75 independent market research and polling firms (WGI 2013). The calculable 105\%, namely, $82 \%-83 \%$ of religious people as shown by Johnson and Ross (2010:36) and 23\% of non-religious people as shown by WGI (2012:2) can be ascribed to the problem of sample size from the WGI survey, as they only surveyed around 1000 people per country. WGI (2012:7) states that a possible 5\% error margin exists because of this relatively small sample size.

Bosch (2013) indicates that the category 'non-religious' does not necessarily mean 'unbelieving', but that most who show themselves to be non-religious still have some form of belief in a deity. This is quite evident in a country like the Netherlands, where a study done by the newspaper 
Trouw (2015) with regard to religious affiliation in the Netherlands indicated that $27 \%$ of the population had a belief in a higher power without any religious connotations.

Christianity has shown a small percentile decline over the last 100 years, from $33.8 \%$ of the global population in 1910 to around $33.2 \%$ of the global population in 2010 (Johnson \& Ross 2010:8). This means that Christianity has simply become part of a larger field of religions and is not the only and most natural option in the western cultural context anymore. This also holds true for South Africa. According to the Pew Research Centre (2011) as much as $80.9 \%$ of South Africa identified themselves as Christian in 2010. The GAC's percentages agree with those of the Pew Research Centre and show that Christianity formed around $82 \%$ of South Africa's population (Johnson \& Ross 2010:9). South Africa also has a lot of religious diversity (Johnson \& Ross 2010:33).

Globalisation is one of the main causes of this diversity (Tiplady 2003:229). Secularism also plays a big part, especially in the questioning of Christianity and religion (Greene \& Robinson 2008:75). This has led to a society where Christian and Muslim, believer and atheist, may be found under the same roof. The question therefore arises as to whether the church can still make an impact within this diverse spectrum, and still be relevant. It is about more than just survival in a global secular society, it is about the nature of the church, the church's self-understanding, that needs to adapt.

One of the areas the church is challenged in, which is also an opportunity, is an area that affects every person, namely the tragedy of death and funerals and the need for bereavement counselling. According to the Central Intelligence Agency (2012), South Africa had the highest mortality rate per 1000 people per year out of 231 countries for the year 2012. This number sat at 17.23 deaths per 1000 people per year, which was significantly higher than the global average of 8 deaths per 1000 people per year. The average life expectancy of someone in South Africa was only 49.4 years in 2012, which was also significantly lower than the global average of 68 years (Ross 2013).

We therefore have a unique situation in South Africa, where the continuous change of society, with globalisation and secularisation as major causal factors, is combined with the tragedy of a significantly high mortality rate. It is in the midst of this tragic situation that the church in South Africa not only has a responsibility and task to guide others through the funeral and grieving process, but she also faces a challenge and simultaneously an opportunity to reach the globalised secular society.

This requires a new approach to death, the funeral and the process of bereavement counselling in order to address the needs of those affected by death in a secular society, whilst simultaneously being an embodiment of Jesus Christ. It is here that missional ecclesiology plays a significant role. The church simply has to grab every opportunity to join the missio Dei and impact an ever-changing society.
This research proposes the following hypothesis:

A missional perspective on funerals and bereavement counselling can support the nature and praxis of congregations in a secular society.

In this research the meaning of missional ecclesiology in a secular society as well as the meaning of mission as action in hope will be examined. This serves as the foundation of this study. Flowing from this research, certain conclusions are then drawn regarding missional ecclesiology and mission as action in hope, which lead to the creation of a missional perspective on funeral and bereavement counselling.

\section{Research methodology}

In this study of mission and evangelism in funerals and bereavement counselling, missional ecclesiology and the secular context, the researcher approaches the research qualitatively.

According to Delport et al. (2005:74), qualitative research points to research that can unlock the participant's own version of meaning, experience or perception of a phenomenon. It includes investigating the world of those involved, from which theories and concepts can be developed, with preference given to participating observations and case studies (Wester 1995:16).

Qualitative methodology accepts that a true understanding of the phenomenon can be gained by formulating the problem, gathering data and analysing those data (Delport et al. 2005:74).

According to Dreyer (1991:247) qualitative research can be placed into the following three categories or methods:

- Participating observation.

- Unstructured or in depth interviewing.

- The use of personal documents.

The researcher uses the method of unstructured or in depth interviewing within the framework of qualitative research to get an in-depth understanding of the world of the participants (Delport et al. 2005:74).

The researcher also does contextual research, which includes interviews with church laity, funeral parlours, counsellors and those influenced by these practices. The researcher attempts to holistically analyse the research gathered inductively with a strong focus on relationships between elements and contexts (Delport et al. 2005:75).

\section{Missional ecclesiology and mission as action in hope}

In the creation of a missional perspective on the funeral and bereavement counselling, the concept of 'mission as action in hope' plays a key role. Bosch (1991:498-499) argues that hope is closely connected to an eschatological expectation of the new heaven and earth, the renewal and transformation of everything that is wrong in the present and future as well as 
the ultimate rule of God. It therefore resonates strongly with missional theology that places a strong emphasis on a Godled transformation of all things.

God is already at work in the world; the question remains as to whether the church is willing to join God in his mission and thereby make the eschatological expectation a reality in the present. This means doing mission in the hope of the transformation of all things. Mission then becomes action in hope (Bosch 1991:510). The church needs to be an agent of this hope.

Hope is the courage to keep standing in the midst of tragedy, to face the future with the hope of the transformation of the present in mind. Hope is one of the most important ingredients in processing pain (Yancey 1990:210). According to Yancey (1990:211), hope saves us from pessimism and the belief that life has no meaning. A person in pain or mourning needs someone, or some kind of thought, that can pull them from the depths of despair to the expectation of the transformation of their current situation.

The answer as to how this transformation needs to take place as well as new perspectives on being church lie within missional ecclesiology. It starts with the missio Dei. Niemandt (2007:147) describes the missio Dei as the mission of the church in the world that belongs to God. The church needs to unite as a community in order to discern God's activity in the world with a view to joining Jesus Christ in his redemptive work.

As part of her missional character, the church needs to be willing to carry the transformative hope into the world. This means that a missional spirituality needs to be developed. It is more than just a calling; it is a spirituality that does not fear change and one that meets fellow travellers in this life in various new ways. Missional spirituality as the spiritual awareness of God's presence and a life within the Trinity (WCC 2012:14) discerns where God's Spirit is at work in the world in order to join God in his mission, as a life in the presence of the Trinitarian God means to be aware of the nature of God as the source of all mission (Balia \& Kim 2010:223).

John 20:21 says: 'As the Father has sent me, I am sending you.' This is a missional calling given by God, and obedience to this missional calling means a journey in life and a journey with God that is inspired and gives birth to a missional spirituality. It is a spirituality that views the church and the world wherein the church lives from a different perspective: it lives a life in the love and incarnation, the embodiment and sacrifice (kenosis), of Jesus Christ, and joins God as sent ones in his redemptive work (Balia \& Kim 2010:233). This calling begins on the doorstep of every believer, and is driven by a new kind of leader, as transformation is inevitable when people experience the love of Christ (Niemandt 2013:31).

The church cannot simply do mission anymore, the church needs to be mission. 1 Peter 2:9 says: 'But you are a chosen people, a royal priesthood, a holy nation, God's special possession, that you may declare the praises of him who called you out of darkness into his wonderful light.' The church here on earth is not the sender, but the one sent. The church exists in being sent and in building itself up for its mission. Mission is not a work of the church, but is simply the church at work (Bosch 1991:372). The church needs to live out the incarnation in both word and deed and make disciples of Christ. It means to bring the good news and to be the good news to a world in need, especially through the creation of relationships and the formation of communities.

Responding to this calling means that the church needs to be a present source of the eschatological hope. It is hope in the transformation of all things through a victory and kingdom that has already come, that is on its way in the present, and that will be here one day (Wright 2008:107). It is therefore hope that is based in the 'already' and the 'not yet' (Brueggemann 2001:69), which is realised by living the incarnation.

This is where the gospel, which testifies to the victory of Jesus Christ, needs to be proclaimed. It is a gospel of hope for all. We therefore do mission in hope - in the hope of the transformation of the present, as well as hope for salvation. It is a living out of hope which has the potential to totally change the world forever. Mission, therefore, becomes action in hope.

Even a new missional language will emerge when this transformation takes place. Language is part of the being of any community or church. This new language is strongly related to expressions such as 'calling', 'to be sent', 'incarnation', 'discipleship', and 'a willingness to cross boundaries' (Niemandt 2010:16). It is a language that takes the missio Dei seriously and nurtures an identity of being sent.

Traditional thoughts concerning evangelism also need to change (Kärkkäinen 2002:18), starting with discipleship. Traditionally the church placed a lot of emphasis on evangelism as going on mission trips to other countries, on 'spreading the gospel' though tracts and crusades, and 'winning souls' for Christ. Evangelism put a lot of emphasis on getting others into heaven, instead of welcoming others to be disciples and followers of Christ. The church cannot simply do evangelism anymore; it needs to live a life based on the incarnate and loving presence of Christ. Space needs to be created for those who do not know Christ to spend time with those who do, without fear of judgement (McManus 2005:1).

The church therefore needs to take unbelievers into account and practise a discipleship that is welcoming. The church then becomes the incarnation of love, which is driven by a new type of leadership that does not rule from a position of power or hierarchy, but is one that, together with others, discerns what God is doing and then participates in it (Niemandt 2013:51). 
In sum, being church means being disciples and making disciples in a world shaken in the midst of various crises. Missional ecclesiology means to partake in the missio Dei, to live out hope in the world, and to make new followers of Christ.

\section{The nature and praxis of the funeral and bereavement counselling process}

It is necessary for the church to be involved in people's stories and bring hope, especially during mourning. In times of death, hope is the one thing that can assist healing in the mourning process (Pattinson 1993:13). Christians have the eschatological hope in the final victory of Christ and the renewal of all things in the future, and even for the reuniting with loved ones, but because of this redemptive act of transformation on Earth they also have hope in the transformation of the present (Wright 2008:14). A relationship with Christ brings the hope of a better life in the future, but also in the present.

During an interview in 2013, Croukamp of AVBOB Rustenburg, a funeral company in South Africa with a branch in Rustenburg, stated that up to $15 \%$ of funerals they handled in 2013 were of non-Christians. Another $15 \%$ had no religion and $40 \%$ did not belong to a church. Coertzen of Martins Funerals Rustenburg indicated similar percentages during an interview in 2014. Both Croukamp and Coertzen stated that the percentages of non-Christians and non-believers have increased rapidly over the last decade and they believe it will continue to do so. They also concurred that more than $90 \%$ of non-Christians and non-believers still opted for some form of funeral, which is then usually held at a Christian place of worship, as has traditionally been done. It is also then conducted by a Christian pastor or reverend, even if the deceased was not known to them.

The church as a whole is still included in the bereavement process, even if only in a small part, as it becomes a place where both Christian and non-Christian meet under the same roof. The church has an opportunity to facilitate healing, to incarnate the loving presence of Christ and bring hope to both Christian and non-Christian, whilst making disciples.

Traditional praxis around the funeral and subsequent bereavement counselling will not be sufficient if the church wants to stay relevant to all those in mourning. Traditionally the deceased and his or her family would have been familiar with and comfortable in a Christian funeral service, but this has changed. The same can be said with respect to the focus of the liturgy that used to include an extensive message of faith. This simply can no longer be assumed in the secular context, with more and more people attending that may not be familiar with even the most basic expressions of faith (Perham 1997:162).

Traditionally the funeral would also have been seen as one of the phases of healing in the mourning process. People would often gather around the bed of the deceased before the funeral arrangements were made. This has also changed with more and more people only attending the funeral service, which means that the funeral itself will have a greater negative impact than before. In the past, most funeral attendees would also have known each other and be able to support one another during the process of mourning. This is not the case anymore (Perham 1997:163).

A new approach is needed in this context, building on the remnants of the old, but taking into account the changing culture and diversity. The church needs to incarnate Christ and practise a discipleship that does not necessarily start with the message of Christian hope, but that welcomes those who do not know Christ to spend time with those who do. This needs to happen throughout the funeral and bereavement counselling process and beyond. It means to love as Christ loved without judgement, and to encourage with the eschatological hope of the transformation of the present and future (Bosch 1991:499).

Funerals and bereavement counselling play an important part in the life of every person in mourning, especially since those who lost loved ones might have lost all hope (Yancey 1990:211). In fact, because of the great psychological and physical effects that the trauma of death has on a person, more than just funerals and bereavement counselling are needed in the grieving process. Perhaps this is where the church can play a part as she has been mandated to share hope to those in mourning. The incarnation, death, and resurrection of Jesus Christ, and the hope attached to these events, can offer this (Bregman 1992:112).

A process of healing takes place where hope is found, because hope helps the person in mourning face the grieving process in the present whilst looking forward to a transformed future. In other words, it leads to a positive goal and hope for the current life (Pattinson 1993:13), which can help to give meaning and direction to one's life, and facilitate reconciliation with God (Louw 1993:375), as God is the initiator of this hope.

Believers, as representatives of God, are tasked to support others in the process of healing and hope. It is their task to be a counsellor, a task that stems from a relationship with God (Kotze 2014). In informal situations, referring to a nonprofessional environment mostly involving a believer not trained in counselling, the believer will act as counsellor in the sense that he or she needs to support those in need by simply being present. In formal situations, referring to a professional environment involving a believer trained in counselling, the counsellor's task involves relieving the suffering of the other person and guiding the other person to a positive goal and hope for his or her life (Pattinson 1993:13). This is possible because of the hope that Christ has given us in his victory over death.

It is therefore about being incarnationally present in the other person's pain and need (Kotze 2014; Pretorius 
2014), helping him or her to live in victory and hope. The impact, change, and recovery of the other person in such conversations is of the utmost importance. The final aim is to facilitate reconciliation with God, to make followers of Jesus Christ (Louw 1993:375). Such conversations, which include bereavement counselling, are therefore a trialogue between God, the counsellor, and the person in mourning (Anderson, Zuehlke \& Zuehlke 2000:113).

The professionally trained counsellor has a holistic role, which includes being sympathetic and empathetic, being impartial, acting with integrity, being explanatory, showing objectivity and realism, and, most important of all, to be lifelike (Collins 1998:26-29). Groenewald (2012) adds that we need to live out our humanity towards others. Although not formally counselling, the non-trained believer should also show these traits when simply supporting others (Kotze 2014; Pretorius 2014).

The grieving process can take up to two years and it is important not to force the process of bereavement counselling, but to constantly show the above-mentioned characteristics during frequent visits (Forrester 1997:117).

Kübler-Ross and Kessler (2005:7) divide the grieving process into the following phases:

1. denial

2. anger

3. negotiation

4. depression

5. acceptance.

A wide variety of emotions are present within each of these phases that exert physical and emotional pressure on the person in mourning. This also means that the person in mourning could develop a pathological grieving process whereby he or she gets stuck in one phase with no healthy outcome in sight if he or she does not seek professional help (Forrester 1997:111-114).

Counsellors are of utmost importance for those in mourning in facilitating final closure and resting, as well as helping with arrangements surrounding the funeral (Coetzer 2014; Kotze 2014; Pretorius 2014). This is where the community of believers has an important role to play in living out the incarnate loving presence and hope of Christ, and if possible, integrate the person in mourning into a community of believers that offer an environment conducive to hope (Forrester 1997:117).

This is also a time when the good news, the hope of Jesus Christ, needs to emerge. The gospel's emphasis on the resurrection and what it means for believers brings a special type of hope to each and every one in mourning. It is a hope for a new world, but a world of which we are already part, a world that gives us hope in the present and the future, a world where everyone in mourning will one day be reunited with the deceased (Forrester 1997:118).
The above-mentioned elements of bereavement counselling and informal counselling are important insights for missional ecclesiology. It is about bringing hope in the midst of despair - a specific kind of hope that is made visible by the counsellor or believer through the above-mentioned elements. This hope needs to become a reality for everyone present at the funeral.

Even though the church has lost a certain degree of influence where funerals and cremations are concerned, this has provided the spacenecessary to think anew about longstanding rituals and symbols in the funeral and cremation service and to address hopelessness in a new way. All symbols, such as flowers pointing to new life, and rituals, such as reading a Bible verse as the coffin is lowered into the grave or as the urn with ashes is placed into a wall of remembrance, need to complement the process of healing and finding final closure, whilst also pointing to a new eschatological hope in Christ (Wepener 2013). The changing western context therefore does not offer a new crisis, but rather a new challenge and opportunity to bring healing to Christians and non-Christians alike, and make disciples of Christ through living out the hope of the transformation of the present and future.

A funeral service or ritual is not only concerned with death, but also with life (Thomas 1997:5). Croukamp (2013) and Coertzen (2014) state that it is also about providing a respectful farewell for the deceased. It needs to celebrate life whilst a message of hope is preached and the deceased is remembered (Thomas 1997:56). It is as though people are invited to sit at the table of the gospel, with Christ at the centre, where the message of hope is proclaimed, whilst reflections on the life of the deceased and the self take place. The Holy Spirit serves as the host and prayer also plays an important part.

There also needs to be a balance between the evangelical and pastoral, meaning that a balance needs to be found between the outright proclamation of the hope of Jesus Christ and the counselling which takes place during the service. The funeral needs to fulfil the spiritual, emotional and physical needs of those in mourning (Coetzer 2014; Wepener 2013).

The role that the funeral fulfils is therefore more than just the farewell of a loved one. Groenewald (2012) states that the funeral is also an opportunity for reaching out, for proclaiming the hope and victory of Jesus Christ in the midst of a secular society. It is a theology of both comfort and hope. The furnishing of the funeral around this goal and theology is not simple. It is important to take the changing secular context into account (Perham 1997:157), so as to be able to function as effectively as possible as an instrument of healing and hope, whilst there remains an encounter between those in mourning and the gospel.

\section{The missional funeral liturgy}

A missional approach to the liturgy of the funeral that moves beyond the traditional approach can achieve the 
above-mentioned aims. The missional funeral liturgy should make both believer and non-believer feel welcome and peaceful from the onset. It should be a liturgy that takes the convincing and sensitive proclamation of the Christian redemption, eschatological hope and faith seriously; it can articulate the feeling of sin, guilt, and failure, and acknowledges that deeds count more than words; it can identify a moment of farewell (Perham 1997:164-168).

It is a liturgy where symbols and rituals play a very important part in pointing to both empathy with the family of the deceased and the new life in following Jesus Christ. It can help the family and friends of the deceased in the grieving process and finding closure (Wepener 2013). It can point to hope in both the present and the future, and is a key part of missional discipleship. The placing of flowers on the coffin is a good example of this. A flower represents new life growing from dust. The placing of a flower on the coffin can be a ritual of farewell for the person in mourning but can also be a ritual of empathy and support, symbolic of the new life in Christ when all things are renewed (Kotze 2014; Wepener 2013). These symbols and rituals are now not only being used as a means of farewell and hope for the afterlife, but also as an integral part of incarnative discipleship, as it brings hope for the present and points to the transformative love and hope of Jesus Christ.

The framework of the liturgy must include the right balance between personal symbols and symbols of the gospel so that the symbolism does not become 'diabolic' in the sense that it does not point to Jesus Christ and the kingdom of heaven and earth, but rather to the deceased, thereby working against the intended goal of reconciliation with and discipleship of Christ (Wepener 2013). There needs to be a drama build-up, which partakes in the missio Dei, around the message of hope. The placing of flowers on the coffin during the farewell ritual is a good example of a symbol that serves both sides, namely: compassion is shown, but the flowers also point to the new life Christ can give, which creates a drama of hope.

The funeral and its liturgy need to be missionally furnished according to this goal. What follows is an example of a missional liturgy for the funeral.

\section{Possibilities for the furnishing of the liturgical space}

- Photos of the deceased or a book of remembrance could be placed in the liturgical space to create an opportunity to remember.

- Flowers could be placed on the coffin to symbolise the life in Christ.

- The cross of Jesus Christ and other symbols that signify the resurrection of Christ always need to symbolically remain central in the liturgical space.

\section{Beginning of the service: Welcoming}

- Word of encouragement: The liturgist can take the context and beliefs of the funeral attendees into consideration in order to promote inclusivity. If the beliefs of the funeral attendees are not compatible with Christian beliefs, a sensitive approach to the word of encouragement through the hope and love of Christ needs to be taken. Paas (2015) suggests using traditionally Christian words subtly within contemporary language, such as 'love', 'faith', 'hope', 'grace', 'holy', 'pray', both in the word of encouragement and if necessary also in the word service and beyond.

- Prayer: This is the first opportunity to pray for hope and comfort, during which an encounter with the gospel is facilitated.

\section{Entry}

- Appropriate word of consolation or hope: An opportunity can be created here that proclaims the hope of Jesus Christ in the context of the community.

- Benediction: Here the opportunity arises to express the blessing of Jesus Christ over everyone in mourning. The crowd can be invited to symbolically sit at the table of the gospel of Jesus Christ. The incarnate presence of God must be made apparent by the believers.

- Song: A song of comfort can be sung or played here.

\section{Word service}

- Prayer: The prayer at this stage is about the revelation of the victory over death from the Word of God.

- Scripture reading: The text needs to proclaim the victory over death and needs to call people to go to the Lord in time of need.

- Preaching: The preaching needs to have a good balance between the direct proclamation of the gospel and pastoral counselling in the gathering. It needs to bring hope and comfort, but also provide a space for reflection on the direction of one's own life. Something of the nature of the resurrection and the renewal of everything can be pointed out here. In the creation of hope, it needs to promote discipleship through the outpouring of incarnational love.

- Prayer: This prayer could provide an opportunity to answer the question of and fulfil the need for a God who is present.

\section{Sending out}

- Tribute: An opportunity is provided for a tribute to the deceased.

- Celebration of life: The use of rituals and symbols are important in this part of the liturgy in order to celebrate the life of the deceased as well as the life and hope that Christ gives. All symbols and rituals need to complement the process of healing and finding final closure whilst pointing to a new eschatological hope. Placing flowers on the coffin, which points to new life in Christ and simultaneously to empathy and a moment of final farewell, or the use of appropriate biblical texts to create a dramatic moment of farewell and closure are important. Everyone attending the funeral should be welcomed 
into this ritual in order to celebrate this life together and become part of the process of healing.

- Giving thanks: An opportunity to thank everyone involved in the funeral as well as to say last goodbyes or a final farewell.

- Reading of the funeral notice: The reading of the funeral notice can be used in the final farewell, which could help with the creation of a dramatic moment that will help with the acceptance.

- Symbolic action: The liturgist can use a symbolic action or ritual here that creates space for remembering the deceased, with a transition that indicates the victory of Christ over death and calls one to reflect on one's own life. An example of this is lighting a candle to symbolise the new life in Christ. This is also part of the process of the final acceptance.

- Song: A song can be played or sung at this stage that creates space for remembering and reflection. Should the liturgist choose that the congregation go outside for the last ritual of farewell or drive behind the hearse to the cemetery, it would form part of the previous part of the final acceptance.

- Blessing: The blessing of the Lord can be shared with the community at this stage and may be done in the form of a common creed if the congregation has gathered around the coffin or as a single creed by the liturgist. This also needs to contribute to the drama and final symbolic action that might help with the final farewell and acceptance.

\section{Another option, if the coffin is taken away by a hearse for cremation}

- Symbolic action: It is an action that creates space to remember but also serves as an opportunity for acceptance and a final farewell whilst creating a sense of community. The placing of flowers on the coffin or the reading of appropriate texts and a final turn away from the coffin as the hearse starts to drive away will be appropriate here.

\section{Another option, if the congregation moves to the grave or columbarium}

- Symbolic action: It is an action that creates space to remember as well as an opportunity for acceptance and a final farewell whilst creating a sense of community. The placing of flowers on the coffin or the reading of appropriate texts or throwing small amounts of dust on the coffin can symbolise the return to dust and the resurrection from the earth. This, coupled with watching the coffin go down into the grave or placing the urn in the columbarium, will be appropriate here.

It is important to remember that the funeral continues, even after the service or ritual at the cemetery or crematorium has been completed. Therefore, consistent support for everyone in mourning is of the utmost importance (Perham 1997:169). This is where the new kind of evangelism based on discipleship is of special importance, as hope and love can be lived and experienced in a smaller personal environment, whilst facilitating reconciliation with Christ.
Practically, this support takes place through bereavement counselling facilitated by a counsellor or believer, or through having a remembrance service for the deceased who has been buried far from all family and friends. It may also take the form of a monthly visit and/or prayer campaign with the person in mourning, and/or creating an awareness of the deceased and their loved ones and friends who stayed behind. Having a remembrance service once a year to remember everyone who has died in the previous year is of importance as it creates a space where Christian hope displaces the feeling of despair (Steel 1997:171).

The funeral message and liturgy need to be adaptable according to personal needs yet maintain the centrality of the message of the hope found in Jesus Christ. It is important that the funeral conveys both hope and healing and that this action does not end when the funeral service or ritual ends. Then death loses its sting.

\section{A missional perspective on the funeral and bereavement counselling}

From the above-mentioned it is clear that a missional perspective on the funeral and bereavement counselling can support the nature and praxis of congregations in secular societies.

The church needs to transform its nature in order to become an agent of hope in its praxis. This hope could be made visible in the funeral service and bereavement counselling process.

The missional church needs to be willing to carry the hope, which she has already experienced through the resurrection of Jesus Christ, into the world and more specifically into aspects of the funeral and bereavement counselling process. Then hope can become an instrument of healing for everyone, even a secular society.

This is especially important at the end of the grieving process, where the church and members of the community play their part to help the person in mourning to reintegrate into the local body of Christ whilst they continue to act as counsellors until hope is found and healing has taken place (Forrester 1997:118).

It is a hope for the future but also a hope for the transformation of the present's despair and despondency which can be realised by living out the incarnation. There is a special kind of affinity between the missional church and expectations of fundamental changes in the future of humankind (Bosch 1991:498-499). The funeral must not be an event where pastoral ministry is the main goal nor must it be simply one where calls to conversion to Christianity overwhelm the funeral attendees. The church needs to approach the funeral missionally with a balance between these two concepts. The liturgy must be constructed as such. By being that part of creation that knows God's unstoppable mission and 
celebrates with thanks and praise in the service, the church can radically change her context.

It is a liturgy with a focus on the missional God and therefore also a liturgy that is constructed according to missional ecclesiology (Perham 1997:162). It is a liturgy that discerningly helps people meet the living triune God in worship and that equips and sends the congregation into life. It always tries to overcome the gap between liturgy and life (NG Kerk 2013:211).

When the sending God becomes the central focus of the service, hope for the salvation and transformation of all things also takes centre stage. The mission of God indeed includes the bringing of hope (Wright 2008:107).

This necessitates that a new missional language be adopted. The church needs to emphasise love, simultaneously empowering people to carry this love to every person in mourning. The church is urged to live out Christ towards each other and to bring hope to every person, even those in mourning. This means to join in the missio Dei and to make disciples of Christ through hope (Wright 2008:107). This means being church as God intended it to be, to be human as God created us to be, and to reach out to others in a secular society where death is often the only event that brings everyone together under the same roof.

The influence of a missional perspective on the funeral and bereavement counselling process in ecclesiology in a secular context is therefore clear. Death can be transformed into hope in the adoption of a missional perspective and the participation in the missio Dei. Mission as action in hope in participating in the missio Dei plays a very important part in and during the funeral and bereavement counselling as it brings the hope of the resurrection and coming kingdom into the present.

It is clear that the creation of a missional perspective on the funeral, and the expansion of the praxis of bereavement counselling with a missional focus, can support the nature and praxis of congregations in a secular society, as stated in the hypothesis.

\section{Conclusion}

In defining hope, as it is applicable to both individuals and mission, it was clear that missional ecclesiology on the one hand and the praxis of funeral and bereavement counselling on the other hand can exercise a great amount of influence on each other. Both should be structured to result in hope. They bring hope specifically where the tragedy of death rules, which is also where a missional approach tries to bring hope by participating in the missio Dei.

The role of the church in changing society will become ever more important (Bosch 1991:408). It is important that the church orientates herself regarding the context of the tragedy in which she finds herself. The church needs to help people in their context, to help them reach a place of peace and hope.

It reminds one strongly of the hope described in 2 Corinthians 4:16-18:

Therefore we do not lose heart. Even though our outward man is perishing, yet the inward man is being renewed day by day. For our light affliction, which is but for a moment, is working for us a far more exceeding and eternal weight of glory, while we do not look at the things that are seen, but at the things that are not seen. For the things which are seen are temporary, but the things which are not seen are eternal.

\section{Acknowledgements Competing interests}

The authors declare that they have no financial or personal relationships which may have inappropriately influenced them in writing this article.

\section{Authors' contributions}

This article is based on research done by P.K. (University of Pretoria) for an MTh degree (Science of Religion and Missiology) under the supervision of C.J.P.N. (University of Pretoria).

\section{References}

Anderson, N., Zuehlke, T. \& Zuehlke, J.S., 2000, Christ-centred therapy: The practical integration of theology and psychology, Zondervan, Grand Rapids, MI.

Balia, D. \& Kim, K., 2010, Edinburgh 2010, vol. II: Witnessing to Christ today, Regnum Books International, Oxford.

Bosch, D., 1991, Transforming mission, Maryknoll, New York, NY

Bosch, J., 2013, 'How religious is South Africa?', viewed 16 March 2013, from http:// evidenceandreason.wordpress.com/2012/08/11/how-religious-is-south-africa/

Bregman, L., 1992, Death in the midst of life, Baker, Grand Rapids, MI.

Brueggemann, W., 2001, Hope for the world: Mission in a global context, Westminster John Knox Press, Louisville, KY.

Central Intelligence Agency, 2012, 'Country comparison death rate', viewed 16 March 2013, from https://www.cia.gov/library/publications/the-worldfactbook/ rankorder/2066 rank.html?countryName=SouthAfrica\&countryCode=sf\&regionC ode=afr\&rank=1\#sf

Coertzen, R., 2014, 'Funerals and statistics', Interview, 14 January 2014.

Coetzer, H., 2014, 'Funerals and rites', Interview, 17 January 2014.

Collins, G., 1998, Christian counselling: A comprehensive guide, Word Publishing Group, Nashville, TN.

Croukamp, F., 2013, 'Funerals and statistics', Interview, 22 September 2013.

Delport, C., De Vos, A., Fouche, C. \& Strydom, H., 2005, Research at grassroots, Van Schaik, Pretoria.

Dreyer, J., 1991, Navorsingsmetodologie, Unisa, Pretoria.

Forrester, D., 1997, 'Loss and Gain', in C.P. Jupp \& T. Rogers (eds.), Interpreting death: Christian theology and pastoral practice, pp. 110-119, Cassell, London.

Frost, M. \& Hirsch, A., 2011, The faith of leap: Embracing a theology of risk, adventure \& courage, Shapevine missional series, Baker, Grand Rapids, MI.

Greene, C. \& Robinson, M., 2008, Metavista: Bible, church and mission in an age of imagination, Authentic, Colorado Springs, $\mathrm{CO}$.

Groenewald, A.J., 2012, 'The funeral and bereavement counselling in a secular and post secular world', Interview, 31 December 2012.

Johnson, T. \& Ross, K., 2010, Atlas of global Christianity, Edinburgh University Press, Edinburgh.

Kärkkäinen, V., 2002, An introduction to ecclesiology: Ecumenical, historical \& global perspectives, Intervarsity Press, Downers Grove, IL.

Kotze, H.P., 2014, 'Counselling in the midst of death', Interview, 04 February 2014.

Kübler-Ross, E. \& Kessler, D., 2005, On grief and grieving: Finding the meaning of grief through the five stages of loss, Simon \& Schuster, London.

Louw, D., 1993, Pastoraat as ontmoeting: Ontwerp vir 'n basisteorie, antropologie, metode en terapie, RGN, Pretoria. 
McManus, E., 2005, 'Erwin McManus on outreach', viewed 16 September 2013, from http://www.churchleaders.com/outreach-missions/outreach-missions-articles/ 139232-erwin-mcmanus-on-outreach.html

National Science Foundation, 1953, 'Third annual report: What is research?', NSF, Arlington.

Nederduitse Gereformeerde Kerk, 2013, 'Agenda vir die vyftiende vergadering van die Algemene Sinode van die Nederduitse Gereformeerde Kerk', NG Kerk, Port Elizabeth.

Niemandt, C.J.P., 2010, 'Five years of missional church: Reflections on missional ecclesiology', Missionalia 38, 397-412.

Niemandt, N., 2007, Nuwe drome vir nuwe werklikhede, Lux Verbi BM, Wellington.

Niemandt, N., 2013, Nuwe leiers vir nuwe werklikhede, Christelike Uitgewersmaatskappy, Vereeniging.

Paas, S., 2015, 'Church planting in a secular society', lecture presented at Department of Theology, University of Stellenbosch, 21 January 2015.

Pattinson, S., 1993, A critique of pastoral care, SCM Press, London.

Perham, M., 1997, 'Anglican funeral rites today and tomorrow', in C.P. Jupp \& T. Rogers (eds.), Interpreting death: Christian theology and pastoral practice, pp. 157-170, Cassell, London.

Pew Research Centre, 2011, Global Christianity, viewed 06 May 2013, from http://www.pewforum.org/interactives/global-christianity/\#/South\%20 Africa, $\% 20 \mathrm{ALL}$

Pretorius, W., 2014, 'Narrative counselling in the midst of death', Interview, 13 February 2014.

Ross, S., 2013, 'The harvest fields, statistics 2013', viewed 16 March 2013, from http:// www.wholesomewords.org/missions/greatc.html\#lolifexp
Steel, G., 1997, 'Celebrating our journey into Christ: The Roman Catholic Order of Christian Funerals', in C.P. Jupp \& T. Rogers (eds.) Interpreting death: Christian theology and pastoral practice, pp. 171-184, Cassell, London.

Thomas, H., 1997, 'Life, death and paradise: The theology of the funeral', in C.P. Jupp \& T. Rogers (eds.), Interpreting death: Christian theology and pastoral practice, pp. 56-66, Cassell, London.

Tiplady, R., 2003, One world or many? The impact of globalisation on mission, William Carey Library, Pasadena, CA.

Trouw, 2015, 'Ongelovigen halen de gelovigen in', viewed 15 April 2015, from www.trouw.nl/tr/nl/5091/religie/article/detail/3830831/2015/01/16/ ongelovigenhalendegelovigenin.dhtml

U.S. Census Bureau, 2013, 'International Data Base', viewed 16 March 2013, from http://sasweb.ssd.census.gov/cgi-bin/broke

Van der Ven, J.A., 1993, Ecclesiologie in context, Kok, Kampen.

Wepener, C., 2013, 'A missional approach to the funeral and bereavement counselling', Interview, 28 August 2013.

Wester, F., 1995, Strategieën voor kwalitatief onderzoek, derde druk, Coutinho, Bussum. WIN GALLOP International, 2012, 'Global index of religion and atheism', RedC, Washington, DC.

WIN GALLOP International, 2013, 'About us', viewed 05 March 2013, from http:// www.wingia.com/en/who_we_are/about_us/

World Council of Churches, 2012, Together toward life: Mission and evangelism in changing landscapes, WCC, Geneva.

Wright, N.T., 2008, Surprised by hope: Rethinking heaven, the resurrection, and the mission of the church, HarperOne, New York, NY

Yancey, P., 1990, Where is God when it hurts? Zondervan, Grand Rapids, MI. 